\title{
South African National Survey of Arachnida: A checklist of the spiders (Arachnida, Araneae) of the Tswalu Kalahari Reserve in the Northern Cape province, South Africa
}

\begin{tabular}{|c|c|}
\hline $\begin{array}{l}\text { Authors: } \\
\text { Anna S. Dipper } \\
\text { Schoeman }{ }^{1,2} \\
\text { Charles R. Had } \\
\text { Robin Lyle }^{1} \\
\text { Leon N. Lotz } \\
\text { Stefan H. Foor } \\
\text { Rudy Jocque }^{5} \\
\text { Peter Webb }\end{array}$ & $\mathrm{d}^{2}$ (1) \\
\hline $\begin{array}{l}\text { Affiliations: } \\
{ }^{1} \text { Biosystematic } \\
\text { ARC - Plant Pr } \\
\text { Research Instit } \\
\text { South Africa }\end{array}$ & $\begin{array}{l}\text { cs Arachnology, } \\
\text { otection } \\
\text { tute, }\end{array}$ \\
\hline $\begin{array}{l}{ }^{2} \text { Department } \\
\text { University of V } \\
\text { South Africa }\end{array}$ & $\begin{array}{l}\text { of Zoology, } \\
\text { lenda, }\end{array}$ \\
\hline $\begin{array}{l}{ }^{3} \text { Department } \\
\text { Entomology, U } \\
\text { the Free State, }\end{array}$ & $\begin{array}{l}\text { of Zoology \& } \\
\text { Jniversity of } \\
\text {, South Africa }\end{array}$ \\
\hline $\begin{array}{l}{ }^{4} \text { Department } \\
\text { National Muse } \\
\text { Bloemfontein, }\end{array}$ & $\begin{array}{l}\text { of Arachnology, } \\
\text { eum } \\
\text { South Africa }\end{array}$ \\
\hline $\begin{array}{l}{ }^{5} \text { Royal Museur } \\
\text { Africa, Tervure }\end{array}$ & $\begin{array}{l}m \text { for Central } \\
\text { en, Belgium }\end{array}$ \\
\hline $\begin{array}{l}{ }^{6} \text { South African } \\
\text { Survey of Arac } \\
\text { South Africa }\end{array}$ & $\begin{array}{l}\text { National } \\
\text { hnida, Pretoria, }\end{array}$ \\
\hline $\begin{array}{l}\text { Corresponding } \\
\text { Charles Hadda } \\
\text { haddadcr@ufs }\end{array}$ & $\begin{array}{l}\text { g author: } \\
\text { d, } \\
\text { s.ac.za }\end{array}$ \\
\hline $\begin{array}{l}\text { Dates: } \\
\text { Received: } 08 \mathrm{~A} \\
\text { Accepted: } 09 \\
\text { Published: } 09\end{array}$ & $\begin{array}{l}\text { Aug. } 2017 \\
\text { Apr. } 2018 \\
\text { July } 2018\end{array}$ \\
\hline 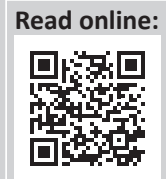 & $\begin{array}{l}\text { Scan this QR } \\
\text { code with your } \\
\text { smart phone or } \\
\text { mobile device } \\
\text { to read online. }\end{array}$ \\
\hline
\end{tabular}

One of the aims of South African National Survey of Arachnida (SANSA) is to survey protected areas to obtain species-specific information and compile inventories to determine species distribution patterns and evaluate their conservation status for Red Data assessments. The aim of this study, the first in a series of surveys of the Diamond Route Reserves, was to compile the first checklist of the spider species in the Northern Cape at the Tswalu Kalahari Reserve. Spiders were collected during three survey periods (2005-2013) using different collecting methods to sample both the ground and field layers. In total, 32 families represented by 108 genera and 136 species have been collected so far. The most species-rich families are the Salticidae (20 spp.) and Thomisidae (18 spp.), followed by the Gnaphosidae and Araneidae (11 spp. each), while nine families are represented by singletons. The free-living wandering spiders represent 97 spp., while 39 spp. are web-builders. Information on spider guilds, endemicity value and conservation status are provided. The Tswalu Kalahari Reserve protects approximately $6.1 \%$ of the total South African spider fauna, while $24.3 \%$ of the species found in the reserve are South African endemics, of which $5.9 \%$ are Northern Cape endemics. Approximately $6.0 \%$ of the species sampled are possibly new to science or represent new records for South Africa.

Conservation implications: The Tswalu Kalahari Reserve falls within the Savanna Biome in the Northern Cape province. Only one spider species was previously known from the reserve; a further $135 \mathrm{spp}$. are reported for the first time, with $5.9 \%$ of the species being Northern Cape endemics and $24.3 \%$ South African endemics. Approximately $6.0 \%$ of the species may be new to science or represent new records for South Africa.

\section{Introduction}

The South African National Survey of Arachnida (SANSA) was initiated in 1997, with the main aim of making inventories of the arachnid fauna of South Africa (Dippenaar-Schoeman \& Haddad 2006; Dippenaar-Schoeman et al. 2015). SANSA has several focus areas, such as arachnid diversity in floral biomes, agroecosystems and protected areas. Species distribution data are an essential information resource needed for the conservation assessments used to compile a Red Data List of the Arachnida of South Africa (Lyle \& Dippenaar-Schoeman 2015). Surveys are needed to obtain species-specific information, and yield new, rare and/or endemic species and resources for these existing protected areas. The publication of these species distribution records formed the basis of the first spider atlas and national species list (Dippenaar-Schoeman et al. 2010; DippenaarSchoeman 2013).

This study presents the results of SANSA sampling in the Tswalu Kalahari Reserve (TKR), falling within the arid parts of the Savanna Biome (Foord, Dippenaar-Schoeman \& Haddad 2011a). The reserve is an E. Oppenheimer \& Son property situated in the Northern Cape (Lyle \& Dippenaar-Schoeman 2013). This is the first survey of the arachnid fauna of protected areas in the Northern Cape province and the first spider checklist for the TKR. Information on spider guilds, their habitat preference, web types, and endemicity index and conservation status are provided. Checklists for several of the protected areas in South Africa have been published but

How to cite this article: Dippenaar-Schoeman, A.S., Haddad, C.R., Lyle, R., Lotz, L.N., Foord, S.H. \& Jocque, R. et al., 2018, 'South African National Survey of Arachnida: A checklist of the spiders (Arachnida, Araneae) of the Tswalu Kalahari Reserve in the Northern Cape province, South Africa', Koedoe 60(1), a1486. https://doi.org/10.4102/koedoe.v60i1.1486

Copyright: @ 2018 . The Authors. Licensee: AOSIS. This work is licensed under the Creative Commons Attribution License. 
none for the Northern Cape (McGeoch et al. 2011; DippenaarSchoeman et al. 2015).

\section{Research method and design Study area and period}

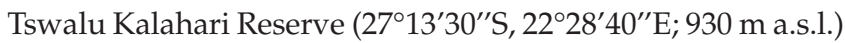
is the largest (> 100000 hectares) privately owned wildlife reserve in South Africa. It lies in the Northern Cape province, at the foot of the Korannaberg Mountains (Figure 1). Kuruman is the closest large town, some $140 \mathrm{~km}$ east of Tswalu.

Tswalu Kalahari Reserve includes vegetation described by Low and Rebelo (1998) as shrubby Kalahari dune bushveld, Kalahari plains bushveld and Kalahari mountain bushveld areas of the Savanna Biome (Figure 2a-d). Acocks (1988) described the area as Kalahari Thornveld. The reserve is characterised in certain areas by scattered shrubs and welldeveloped grass layers, in other areas by a well-developed tree layer and moderately developed grass and shrub layers, and by a poorly developed tree layer and moderately developed grass layers on the mountains and hills (Van Rooyen 1999). Some dominant plant species include the trees Vachellia erioloba, Boscia albitrunca and Terminalia sericea. The four main soil types in the TKR are poorly structured red soils with a high base status; well-drained red, sandy soils with a high base status; red and yellow, well-drained sandy soils with a high base status; and rocky areas with little or no soil (Van Rooyen 1999).
The climate of TKR is highly variable and falls in the summer rainfall area of southern Africa (Low \& Rebelo 1998), with a relatively high rainfall occurring from October to April but with a distinct peak in March. The mean annual rainfall is $253.3 \mathrm{~mm}$. The dry season occurs from May to September, with an average of less than $10.0 \mathrm{~mm}$ during this period. The peak dry season occurs from June to August, with little or no rainfall.

\section{Sampling methods and identification}

Material from three surveys (Table 1) was used to compile the first checklist of the spiders of TKR (Appendix 1). During the first visit to the reserve, spiders were collected ad hoc in all five habitats in the reserve (Figure 1) using a variety of methods, and no set protocol was followed. The second and third surveys were carried out using the standardised protocol devised for SANSA and described in detail by Haddad \& Dippenaar-Schoeman (2015). It can be briefly summarised as follows: four representative habitats in a selected degree-square grid were selected by the field work manager, in this case the third author, and sampled by a team of four collectors. During the second and third surveys, sampling was carried out in grass layer around hills forming part of the Korannaberg-Langeberg Mountain Bushveld, Olifantshoek Plains Thornveld, Gordonia Plains Shrubland and Kathu Bushveld (Figure 1).

In each of these habitats sampled using the SANSA protocol, 500 beat samples were taken from woody

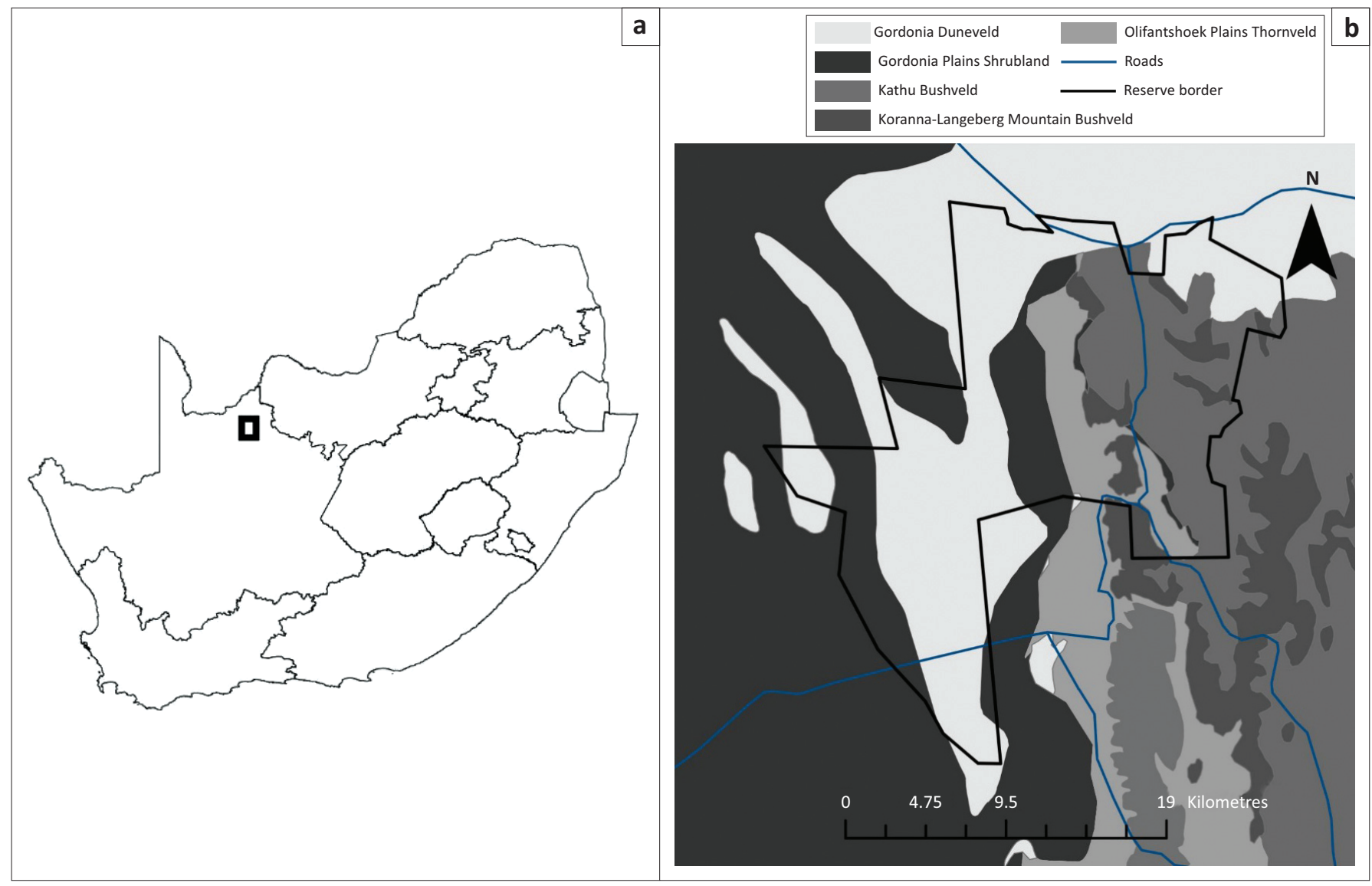

FIGURE 1: (a) Map of South Africa, showing the locality of the Tswalu Kalahari Reserve in Northern Cape province; and (b) details of the vegetation units in the reserve. 

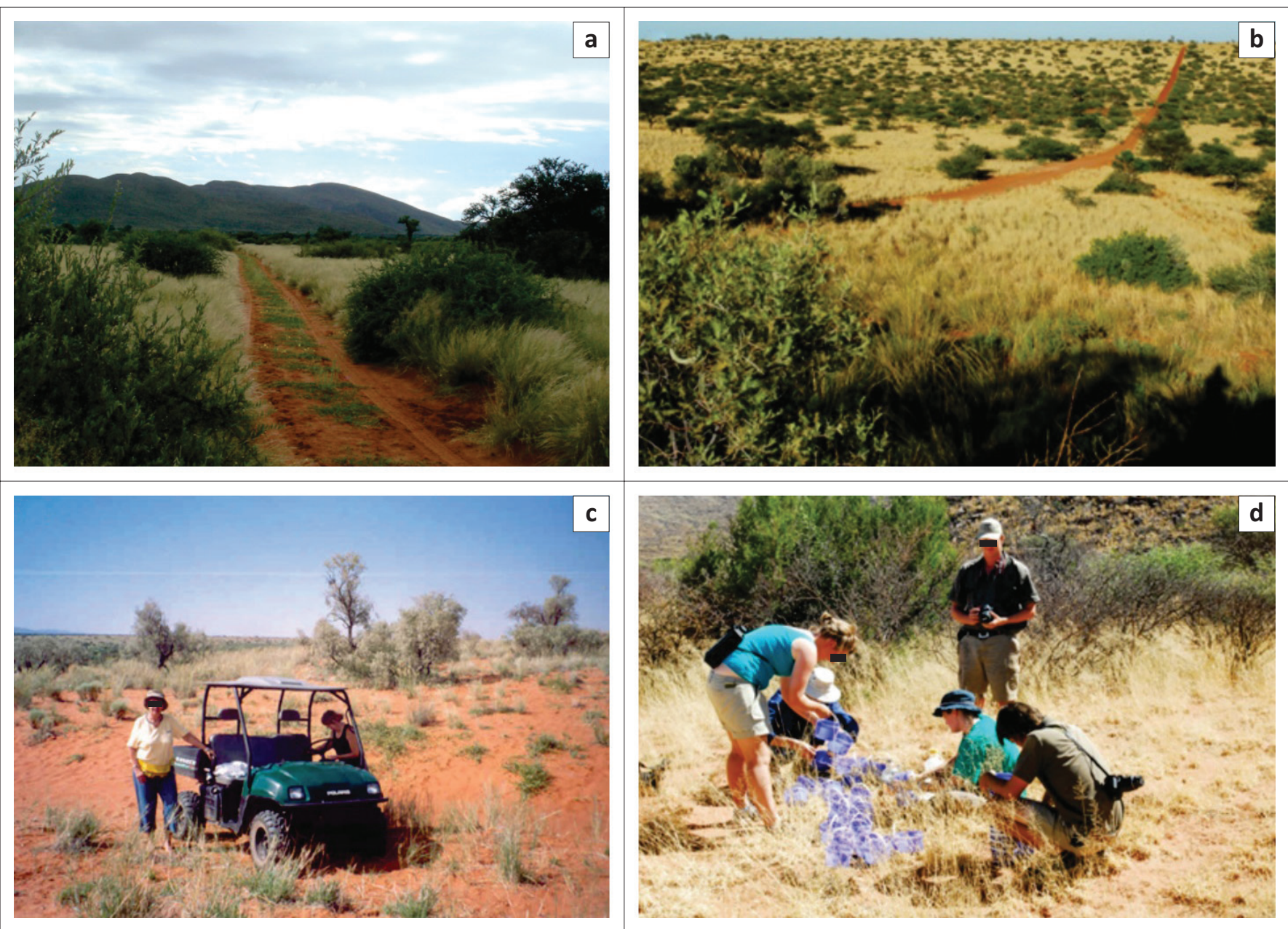

FIGURE 2: Habitat types in the Tswalu Kalahari Reserve: (a) Well-developed grass layer near the foothills of the Korannaberg Mountains; (b) Kalahari Thornveld; (c) Sand dune with poorly developed tree layer and moderately developed grass; and (d) One of the South African National Survey of Arachnida sampling sites.

TABLE 1: Details of spider surveys undertaken at the Tswalu Kalahari Reserve during three field trips, including some of the authors of this article.

\begin{tabular}{lllc}
\hline Survey team & Sampling protocol & Date & Sampling days \\
\hline $\begin{array}{l}\text { Anna Dippenaar- } \\
\text { Schoeman and Rudy } \\
\text { Jocqué }\end{array}$ & Ad hoc sampling & February 2005 & 8 \\
$\begin{array}{l}\text { Robin Lyle and } \\
\begin{array}{l}\text { Agricultural Research } \\
\text { Council (ARC) team }\end{array}\end{array}$ & $\begin{array}{l}\text { SANSA rapid } \\
\text { sampling protocol }\end{array}$ & February 2010 & 4 \\
$\begin{array}{l}\text { ARC team (Robin Lyle), } \\
\begin{array}{l}\text { National Museum } \\
\text { (Leon Lotz) and Peter }\end{array}\end{array}$ & $\begin{array}{l}\text { SANSA rapid } \\
\text { Sebb }\end{array}$ & Mampling protocol 2013 & 4 \\
\hline
\end{tabular}

SANSA, South African National Survey of Arachnida.

vegetation using a beating sheet and beating stick; 500 sweep samples were taken from grasses and herbaceous vegetation using a sweep net; 50 pitfall traps (buckets with diameter of $135 \mathrm{~mm}$ ) were set out $2 \mathrm{~m}$ apart and kept open for 3-4 days; ten leaf litter samples were taken and sifted over a white sheet using a steel sieve with a mesh spacing of $9 \mathrm{~mm}$. Further, in each habitat, all four team members conducted $2 \mathrm{~h}$ of hand collecting during the day from beneath logs, rocks and bark and from vegetation. Night collecting ( $2 \mathrm{~h}$ per person) was done in all four habitats, as opposed to the single habitat required by the SANSA protocol. Winkler traps were used to extract leaf litter samples taken in a single habitat (Olifantshoek Plains Thornveld) during the second survey only; this method yielded poor results and was not used during the third survey.

All of the material sampled for each of the above methods was preserved in $70 \%$ ethanol, except for pitfall traps, in which propylene glycol was used as a preservative. Once the pitfalls were removed from the soil, the material was sieved, and the arachnids removed and preserved in $70 \%$ ethanol.

Species determinations were performed by several of the authors. Voucher specimens are deposited in the National Collection of Arachnida housed at the ARC-Plant Protection Research, Pretoria (NCA), and at the National Museum in Bloemfontein (NMBA). Only the generic names were included in the checklist when immature specimens were sampled and in those cases where the family lacks taxonomic resources to make species level identifications possible.

\section{Functional groups}

Spiders often live in distinct microhabitats with limitations imposed by contrasting biotic and abiotic factors. Species can be categorised into particular functional groups or guilds, based on our knowledge of their habitat and microhabitat 
TABLE 2: Detailed descriptions of foraging guilds that were assigned to spider species sampled in the Tswalu Kalahari Reserve.

\begin{tabular}{|c|c|c|}
\hline Guild & Abbreviation & Description \\
\hline \multicolumn{3}{|l|}{ Wanderers (W) } \\
\hline \multirow[t]{2}{*}{ Ground wanderers (GW) } & BGW & $\begin{array}{l}\text { Ground-dwelling spiders that live in } \\
\text { permanent burrows constructed in the } \\
\text { soil; males often wander in search of } \\
\text { females. }\end{array}$ \\
\hline & FGW & $\begin{array}{l}\text { Free-living ground-dwelling spiders that } \\
\text { actively forage on the soil surface; many } \\
\text { species hide, construct retreats and egg } \\
\text { sacs under rocks or logs. }\end{array}$ \\
\hline Plant wanderers (PW) & PW & $\begin{array}{l}\text { Free-living plant-dwelling spiders that } \\
\text { actively forage on vegetation; most } \\
\text { species construct retreats and egg sacs } \\
\text { in flowers, leaves or grasses. }\end{array}$ \\
\hline \multicolumn{3}{|l|}{ Web-builders (WB) } \\
\hline Funnel-web builders & FWB & $\begin{array}{l}\text { Webs constructed over the soil surface } \\
\text { and low vegetation, with a funnel- } \\
\text { shaped retreat at one end of the web, } \\
\text { often constructed with the retreat } \\
\text { under rocks or logs, or in low shrubs, } \\
\text { grass tussocks and bushes. }\end{array}$ \\
\hline Gumfoot-web & GWB & $\begin{array}{l}\text { Three-dimensional webs comprising a } \\
\text { central area with or without a retreat. } \\
\text { The upper section includes mooring, } \\
\text { signal and catch threads, and the lower } \\
\text { part includes mooring and catch } \\
\text { threads. The latter threads are studded } \\
\text { with sticky droplets close to the } \\
\text { substrate that ensnare prey. }\end{array}$ \\
\hline $\begin{array}{l}\text { Modified orb-web } \\
\text { builders }\end{array}$ & MOWB & $\begin{array}{l}\text { Spiders with orb-web building ancestors } \\
\text { that have evolved to capture prey using } \\
\text { a reduced web, sometimes only a single } \\
\text { silk strand with a distal droplet of gluey } \\
\text { silk. }\end{array}$ \\
\hline Orb-web builders & OWB & $\begin{array}{l}\text { Webs are predominantly built in } \\
\text { vegetation and consist of an upper } \\
\text { horizontal bridge line supporting a } \\
\text { frame with mooring lines, regular radial } \\
\text { signal threads converging at the hub of } \\
\text { the web, and circular spiral threads. }\end{array}$ \\
\hline Retreat-web & RWB & $\begin{array}{l}\text { Webs comprising silk threads used to } \\
\text { catch prey that radiate from a retreat, } \\
\text { usually made with cribellate silk and } \\
\text { considerably variable in density } \\
\text { between taxa. }\end{array}$ \\
\hline Sheet-web & SHWB & $\begin{array}{l}\text { Webs that usually comprise an upper } \\
\text { densely woven sheet with mooring, } \\
\text { signal and catch threads, usually } \\
\text { without a distinct retreat. }\end{array}$ \\
\hline Space-web & SPWB & $\begin{array}{l}\text { Irregular webs that fill open spaces } \\
\text { between vegetation, or under rocks, } \\
\text { logs and in animal burrows. }\end{array}$ \\
\hline
\end{tabular}

Source: Adapted from Foord, S.H., Dippenaar-Schoeman, A.S. \& Haddad, C.R., 2011a, 'South African spider diversity: African perspectives on the conservation of a mega-diverse group', in O. Grillo \& G. Venora (eds.), Changing diversity in changing environment, pp. 163-182, In Tech Publishing, Rijeka

SPWB, space-web builders; SHWB, sheet-web builders; RWB, retreat-web builders; OWB, orb-web builders; MOWB, modified orb-web builders; GWB, gumfoot-web builders; FWB, funnel-web builders; PW, plant wanderers; FGW, free-living ground wanderers; BGW, burrow-dwelling ground wanderers.

preferences, as well as their diets and hunting strategies (Foord et al. 2011a). This provides valuable ecological information that helps in better understanding the utilisation of habitat structures by different taxa. In general, spiders can be divided into species that are largely or entirely reliant on silk to construct webs to capture prey (web-builders, WB) and those that actively search for prey or ambush prey from burrows or on vegetation (wanderers, W). Each of these two major guilds is divided into several subcategories based on the substrates they utilise or the web types that they construct (Table 2).

\section{Endemicity value}

The conservation status of species is important, and as part of the First Atlas of South African Spiders (Dippenaar-Schoeman
TABLE 3: Level of endemicity of the 136 spider species sampled at the Tswalu Kalahari Reserve.

\begin{tabular}{lccc}
\hline Distribution & No. spp. & $\mathbf{\%}$ & Conservation status \\
\hline Not evaluated & 10 & 7.4 & DDT \\
0-Africa and wider & 8 & 5.9 & LC \\
1-Afrotropical & 50 & 36.8 & LC \\
2- Southern Africa & 35 & 25.7 & LC \\
3- Widespread in South & 19 & 14.0 & SAE \\
Africa, $\geq 3$ provinces & & 4.4 & SAE \\
4- Two adjacent provinces & 6 & 5.9 & NCE \\
5- One province & 8 & - & RE \\
6- Only type locality & 0 &
\end{tabular}

DDT, data deficient for taxonomic reasons; LC, Least Concern; NCE, Northern Cape province Endemic; RE, Reserve Endemic; SAE, South African Endemic. spp. species.

et al. 2010), an endemicity index was provided for each species (Table 3, Appendix 1) based on its current distribution. Seven endemicity categories were considered: $6=$ endemic, known only from type locality or one locality only; $5=$ known from one province only, wider than type locality; $4=$ known from two adjoining provinces only; $3=$ South Africa, known from more than two provinces or two provinces not adjoining; 2 = southern Africa (south of Zambezi and Kunene Rivers); 1 = Afrotropical Region; 0 = Africa and wider.

Regarding conservation status, species that were only recorded from immatures or that represent new taxa were not evaluated, and are considered to be data deficient for taxonomic reasons (DDT). Species with a broad distribution (categories 0-2) were considered to be of Least Concern (LC); those of categories 3 and 4 were considered to be South African endemics (SAE); and those of category 5 were considered to be Northern Cape endemics (NCE). No Reserve Endemics (RE, category 6) have been recorded from TKR yet.

\section{Photography}

As part of SANSA, a photographic Virtual Museum was developed to access photographs of arachnid species (Dippenaar-Schoeman, Lyle \& Van den Berg 2012; DippenaarSchoeman et al. 2015). Spiders sampled during the last surveys at TKR were photographed by the last author. A photo gallery of the spiders will be made available on the SANSA website. Images can also be viewed at http:/ / www. arc.agric.za:8080/Default.

\section{Ethical considerations}

Permission to collect arachnids in the Northern Cape province was obtained from the Northern Cape Department of Environment and Nature Conservation.

\section{Results and discussion Spider biodiversity and endemicity}

Thirty-two spider families represented by 108 genera and 136 spp. were collected from TKR between 2006 and 2013 over a total of 16 sampling days (Appendix 1, Table 4). Except for one species, Tusitala barbata Peckham \& Peckham, 1902 
TABLE 4: Spider diversity of Tswalu Kalahari Reserve, with total number of families, genera and species sampled.

\begin{tabular}{lcclcc}
\hline Families & GEN. & SPP. & Families & GEN. & SPP. \\
\hline Agelenidae & 3 & 4 & Palpimanidae & 2 & 2 \\
Ammoxenidae & 1 & 1 & Philodromidae & 4 & 6 \\
Araneidae & 9 & 11 & Pholcidae & 1 & 1 \\
Caponiidae & 2 & 2 & Pisauridae & 2 & 2 \\
Clubionidae & 1 & 1 & Prodidomidae & 2 & 3 \\
Cyrtaucheniidae & 1 & 1 & Salticidae & 16 & 20 \\
Dictynidae & 1 & 1 & Scytodidae & 1 & 1 \\
Eresidae & 3 & 4 & Selenopidae & 1 & 1 \\
Eutichuridae & 2 & 2 & Segestriidae & 1 & 3 \\
Gnaphosidae & 8 & 11 & Sicariidae & 2 & 2 \\
Hersiliidae & 2 & 3 & Sparassidae & 3 & 3 \\
Linyphiidae & 2 & 2 & Theraphosidae & 3 & 3 \\
Lycosidae & 6 & 6 & Theridiidae & 7 & 8 \\
Migidae & 1 & 1 & Thomisidae & 13 & 18 \\
Mimetidae & 1 & 1 & Uloboridae & 1 & 3 \\
Oxyopidae & 3 & 6 & Zodariidae & 3 & 3 \\
\hline TOTAL & & & 32 & $\mathbf{1 0 8}$ & $\mathbf{1 3 6}$ \\
\hline
\end{tabular}

GEN., genera; SPP., species sampled.

(Salticidae), the rest of the species are reported from the reserve for the first time (Azarkina \& Foord 2015). Although the Northern Cape is South Africa's largest province, covering $29.7 \%$ of the land area, only 1990 records sampled from 124 sites in the Northern Cape are accessioned in the SANSA database, represented by 490 spp. from 49 families (Dippenaar-Schoeman et al. 2015).

The Northern Cape province has been less intensively sampled than the other provinces. Except for the field guide on the spiders of the Kalahari (Dippenaar-Schoeman \& Van den Berg 2010), no surveys from protected areas in the province have been published. Several surveys are underway in reserves (Benfontein, Rooipoort and Oryx Nature Reserves) and in the Augrabies, Richtersveld and Namaqua National Parks (Lyle \& Dippenaar-Schoeman 2013; DippenaarSchoeman 2014a). The only published results are surveys in pistachio orchards in the arid Nama Karoo near Prieska (Haddad \& Dippenaar-Schoeman 2005, 2006; Haddad, Dippenaar-Schoeman \& Pekár 2005; Haddad, Louw \& Dippenaar-Schoeman 2004; Haddad, Louw \& Pekár 2008), where a total of $143 \mathrm{spp}$. from 31 families were collected (Foord et al. 2011a). In a second study, Lyons (2009) conducted a broad-scale survey of arthropods in restored alluvial diamond mining sites in the Succulent Karoo of the Northern Cape, in which 21 spider families and $51 \mathrm{spp}$. were sampled.

Based on these results and information from the SANSA database, the number of species sampled in reserves and parks in the Northern Cape is much lower (80-140 spp.) compared to Limpopo reserves, which average 228 spp. per reserve, ranging between 175 and 286 spp. (Foord et al. in prep.).

Of the 136 spp. sampled, ten spp. (7.4\%) were DDT and could not be identified to species level, of which four spp. were immature and six spp. are possibly new to science (Appendix 1, Table 3). However, these putative new species are representatives of species-rich families, and only after revisionary studies would it be possible to tell whether they are indeed new to science. No species sampled from TKR thus far can be considered RE. Only the South African endemic species falling into categories 3-6 (33 spp., 24.3\%) need to be evaluated using the IUCN criteria. The majority of the species sampled (93 spp.) can be listed as LC, having a distribution throughout southern Africa or wider (Table 3).

Seven Northern Cape endemic species are protected in the TKR: Ancylotrypa pusilla Purcell, 1903 (Cyrtaucheniidae) (Figure 3a); Dresserus laticeps Purcell, 1904 (Eresidae) (Figure 3b); Allocosa aurichelis Roewer, 1959 (Lycosidae) (Figure 3c); Aelurillus cristatopalpus Simon, 1902 (Salticidae); Evarcha brinki Haddad \& Wesołowska, 2011 (Salticidae); Ariadna jubata Purcell, 1904 (Segestriidae) (Figure 3d) and Histagonia deserticola Simon, 1895 (Theridiidae).

During this study, Ibala okorosave Fitzpatrick, 2009 (Gnaphosidae) was recorded from South Africa for the first time, and the first adult specimens of the monotypic genus Mallinus Simon, 1893 (Zodariidae) were also sampled. Currently, 2240 spider species are known from South Africa (Dippenaar-Schoeman 2017), and thus, $6.1 \%$ of South African species are protected in this reserve.

\section{Family diversity}

Results from the Savanna Biome indicate that four spider families consistently dominate assemblages in terms of species richness (Foord, Dippenaar-Schoeman \& Haddad 2011b; Dippenaar-Schoeman, Foord \& Haddad 2013): Araneidae, Gnaphosidae, Salticidae and Thomisidae. In this study, the Salticidae (20 spp.), Thomisidae (18 spp.), Gnaphosidae (11 spp.) and Araneidae (11 spp.) were the most species-rich families (Table 4), consistent with patterns in the Savanna Biome. Nine families are represented by singletons.

Salticidae: The Salticidae are free-living spiders found on vegetation and the soil surface. They build small silk nests attached to various substrates, in which they moult, oviposit and sometimes mate, or which they occupy during periods of inactivity (Dippenaar-Schoeman \& Van den Berg 2010; Dippenaar-Schoeman 2014b). During the last survey of this study, a small round densely woven silk retreat attached to grass (Figure 3e) was sampled in the TKR, housing an immature Thyene imperialis (Rossi 1846). One species has been identified as belonging to a new genus (Galina Azarkina, pers. comm.) and one was immature. The other 17 are new records for the TKR, five spp. are SAE, two spp. are NCE, while $11 \mathrm{spp}$. are more widely distributed throughout Africa (Appendix 1).

Thomisidae: Crab spiders are free-living spiders commonly found on grass, shrubs, flowers and trees, and only few species were sampled from the soil surface (DippenaarSchoeman \& Van den Berg 2010; Dippenaar-Schoeman 2014b). Thomisids are easily dispersed by wind and most species have a wide distribution. In the TKR, 13 genera represented by $18 \mathrm{spp}$. were sampled. Of these, only four spp. 

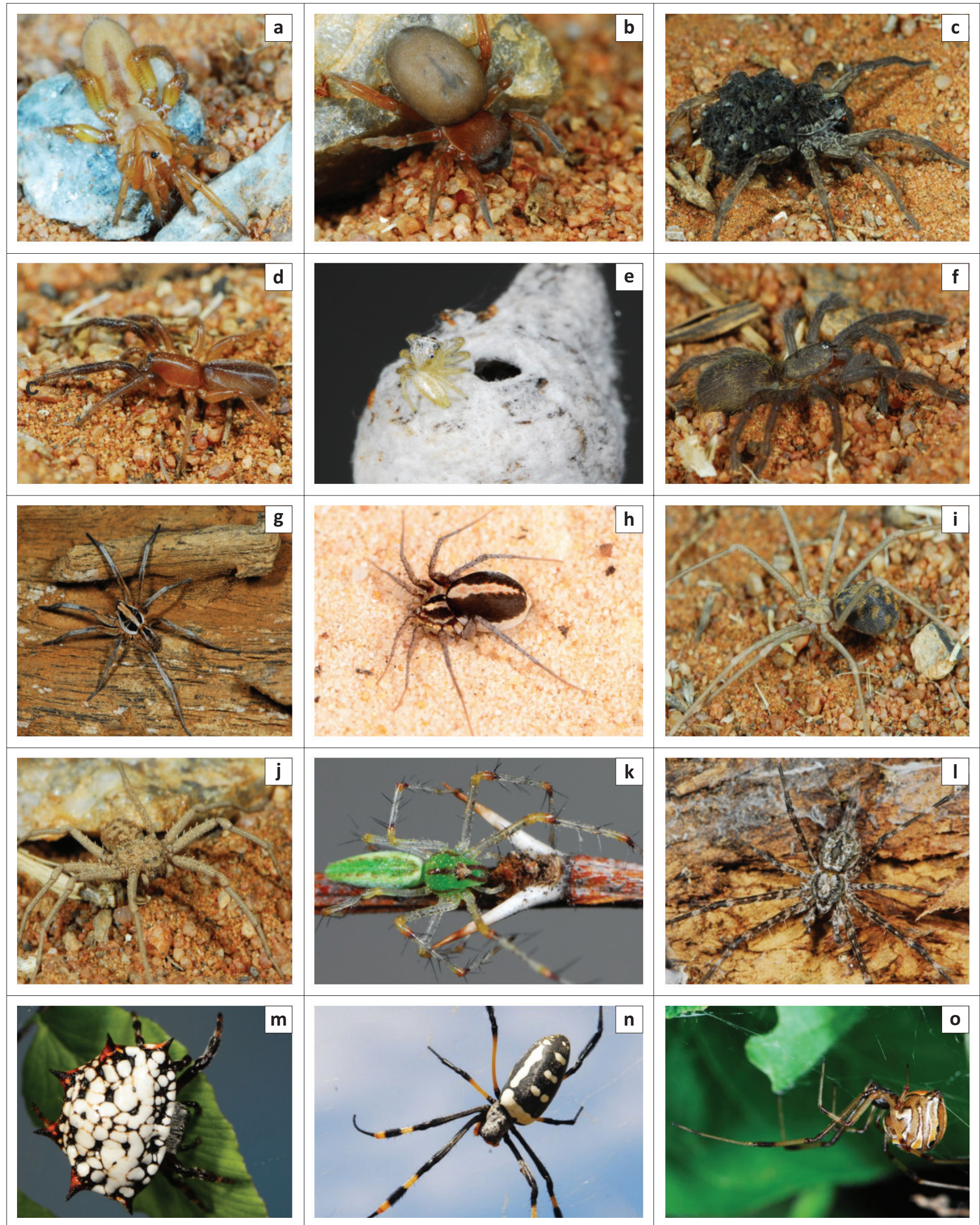

FIGURE 3: Spiders of the Tswalu Kalahari Reserve: (a) Ancylotrypa pusilla (Cyrtaucheniidae); (b) Dresserus laticeps (Eresidae); (c) Allocosa aurichelis (Lycosidae); (d) Ariadna jubata (Segestriidae); (e) Nest of immature Thyene imperialis (Salticidae); (f) Harpactirella lapidaria (Theraphosidae); (g) Hogna transvaalica (Lycosidae); (h) Ammoxenus coccineus (Ammoxenidae); (i) Loxosceles simillima (Sicariidae); (j) Sicarius testaceus (Sicariidae); (k) Peucetia viridis (Oxyopidae); (I) Hersilia sericea (Hersiliidae); (m) Isoxya mossamedensis (Araneidae); (n) Nephila senegalensis (Araneidae); and (o) Latrodectus geometricus (Theridiidae). 
are known SAE, while the rest (14 spp.) are widely distributed throughout Africa (Appendix 1).

Gnaphosidae: The gnaphosids are free-living spiders commonly found on the ground and low vegetation (Dippenaar-Schoeman \& Van den Berg 2010; DippenaarSchoeman 2014b). One species could not be determined, five of the 11 spp. are SAE, and the rest have a wide distribution. One species, Aneplasa nigra Tucker, 1923, has a restricted distribution and is known from the Northern and Western Cape provinces only (Appendix 1).

Araneidae: The Araneidae are web-builders and produce typical orb-webs (OWB) and modified orb-webs (MOWB) (Dippenaar-Schoeman \& Van den Berg 2010; DippenaarSchoeman 2014b). All the members of the family (11 spp.) recorded here have a wide African distribution.

\section{Functional groups}

For this study, two main guilds were recognised, namely wandering spiders (W) (97 spp.) and web-builders (WB) (39 spp.), with further subdivisions based on microhabitat and general behaviour, as observed during surveys (Appendix 1).

Wanderers: A total of 97 spp. (71.3\%) are wandering spiders, with some species living on vegetation (39 spp.) and others on the ground surface (55 spp.), with an additional three species occurring regularly in both strata. The majority of ground-dwellers are free-living soil dwellers (58 spp., 42.6\%), while six spp. (4.4\%) live in burrows. The Salticidae (15 spp.), Gnaphosidae (11 spp.) and Lycosidae (six spp.) are the most species rich families of ground-dwellers (Appendix 1).

Most of the burrow-dwellers belong to the suborder Mygalomorphae and include the trapdoor spider species Ancylotrypa pusilla (Figure 3a), a bag-nest migid, Moggridgea peringueyi Simon, 1903, and three theraphosid baboon spider species (Figure 3f). One species of wolf spider, possibly Hogna transvaalica (Simon, 1898) (Lycosidae) (Figure 3g), also constructs burrows. These spiders use their bright red cheliceral setae to scare off predators (Webb 2013).

A species of the termite-eating spider, Ammoxenus coccineus Simon, 1893 (Ammoxenidae), was sampled from loose sand (Figure 3h). Ammoxenids are specialist termite-feeders (Petráková et al. 2015) and use the strong setae on their chelicerae to dive into the sand (Dippenaar-Schoeman, De Jager \& Van den Berg 1996a; Dippenaar-Schoeman, De Jager \& Van den Berg 1996b). Two species of medical importance were sampled at TKR, the violin spider Loxosceles simillima Lawrence, 1927 (Sicariidae) (Figure 3i) and the six-eyed sand spider Sicarius testaceus Purcell, 1908 (Sicariidae) (Figure 3j).

The plant wanderers sampled from the grass and tree layer are represented by $42 \mathrm{spp}$. (30.9\%). The Thomisidae (16 spp.), Salticidae (eight spp.) and Oxyopidae (six spp.) were the most diverse plant-dwellers found on grasses, shrubs and trees. Three salticid species occur both on the ground and on vegetation (Appendix 1). Some interesting results have already been published regarding the presence of Peucetia viridis (Blackwall, 1858) (Figure 3k) of the family Oxyopidae, which was sampled from the unpalatable Kalahari sour grass (Bushman's Grass), Schmidtia kalahariensis. This annual grass is only available for a short period after good rains. It has an unpleasant smell and is covered with glands that produce an acidic substance. During the survey in 2008, this was the dominant grass present and it was intensively swept, but only this one species was recorded from the grass (DippenaarSchoeman 2005; Vasconcellos-Neto et al. 2007).

Several species were sampled from trees, including the long-spinnered bark spiders, Hersilia sericea Pocock, 1898 (Hersiliidae) (Figure 31), and the community nest spiders, Stegodyphus dumicola Pocock, 1898 (Eresidae).

Web-dwellers: The web-dwellers are represented by $39 \mathrm{spp}$. $(28.7 \%)$, with the largest number making OWB or MOWB (14 spp., 10.3\%), followed by gumfoot-webs (eight spp., 5.9\%), retreat-webs (eight spp., 5.9\%), funnel-webs (five spp., 3.7\%), sheet-webs (three spp., 2.2\%) and space-webs (one sp., 0.7\%).

The physical structure of the habitat plays a role in the composition of the web-dwelling fauna, as it not only provides the necessary support for anchoring webs but also increases the availability of retreat space and modification of the microclimate, which could have an effect on spiders, as well as their prey. Most of the OWB recorded belong to the Araneidae (11 spp.) (Figure 3m and n), which construct large orb-webs between trees and shrubs. Some of these species are diurnal and they are found in their webs during the day. Some orb-web builders are associated with grasslands (Araneus, Larinia, Nemoscolus and Neoscona) and are mostly nocturnal, making their orb-webs at night and resting in retreats, usually constructed in grass inflorescences, during the day. One species is a MOWB, the tropical tent-web spider (Cyrtophora citricola [Forsskål, 1775]). Several gumfoot-web spiders of the Theridiidae (eight spp.) were sampled, including two button spiders that are of medical importance, Latrodectus geometricus C.L. Koch, 1841 (Figure 3o) and L. renivulvatus Dahl, 1902.

\section{Conclusion}

As signatories to the Convention on Biodiversity, South Africa has an obligation to develop a strategic plan for the conservation and sustainable utilisation of its fauna and flora. Preliminary investigations into the biodiversity of the South African Arachnida highlighted the obstacles caused by a lack of baseline biodiversity and ecological information for many of the arachnid orders (Dippenaar-Schoeman 2002). With this in mind, each biodiversity survey contributes to improving our knowledge of the geographical distribution and biology of South African spider species. This survey forms part of the SANSA for the Savanna Biome, as well as the Northern Cape province, and as such 
represents new provincial records for 102 species. Although this article probably represents only a portion of the spider fauna present, we hope that this information will stimulate further interest and research. Established reserves, such as TKR, can make a substantial contribution towards invertebrate conservation. However, the contribution of existing reserves can only be highlighted through studies such as this.

\section{Acknowledgements}

The authors would like to thank the Agricultural Research Council (ARC) and the South African National Biodiversity Institute's (SANBI) Threatened Species Programme for funding the South African National Survey of Arachnida (SANSA) phase 2; Duncan MacFadyen of E. Oppenheimer \& Son trust for providing permission to sample in Tswalu Kalahari Reserve and the officials of Tswalu for their friendliness and assistance; the staff of the Arachnology section of the Biosystematics Programme, ARC - Plant Protection Research, notably Connie Anderson, Sma Mathebula and Petro Marais, for their assistance with processing the material collected; Elisabeth Tybaert (wife of Rudy Jocqué), Petro Marais and Michael Stiller (ARC) for assisting during the fieldwork; and Galina Azarkina for assistance with the Salticidae identifications.

\section{Competing interests}

The authors declare that they have no financial or personal relationships that may have inappropriately influenced them in writing this article.

\section{Authors' contributions}

All the authors are team members of SANSA and contributed towards planning this national survey. They participated in field work, identifications of specimens and curation of material. A.S.D-S. and R.L. were involved in surveys, identifications and preparation of the manuscript; C.R.H. assisted with editing the manuscript; L.N.L. and R.J. assisted with field surveys; P.W. participated in field surveys and photographed all the specimens

\section{Funding information}

The first, second and fifth authors acknowledge financial support from the National Research Foundation of South Africa.

\section{References}

Acocks, J.P.H., 1988, 'Veld types of South Africa', 3rd edn., Memoirs of the Botanical Survey of Southern Africa 57, 1-146.

Azarkina, G.N. \& Foord, S.H., 2015, 'A review of three Tusitala (Araneae: Salticidae) species from southern Africa, with a new synonymy and description of a new species from Botswana', African Invertebrates 56, 285-307. https://doi.org/ 10.5733/afin.056.0204

Dippenaar-Schoeman, A.S., 2002, 'Status of South African Arachnida Fauna', Proceedings of the symposium on the Status of South African species organized by the Endangered Wildlife Trust (EWT) of South Africa, Rosebank, September 4-7, 2001, pp. 70-81.
Dippenaar-Schoeman, A.S., 2005, 'Interesting behaviour of a green lynx spider collected at Tswalu Game Reserve (Araneae: Oxyopidae: Peucetia)', Spider Club News 20, 8-9.

Dippenaar-Schoeman, A.S., 2013, 'First national species lists of South African arachnids available', Plant Protection News 95, 6.

Dippenaar-Schoeman, A.S., 2014a, 'What is new in SANSA - and plans for 2014', SANSA News 19, 3-6.

Dippenaar-Schoeman, A.S., 2014b, Field guide to the Spiders of South Africa, Lapa Publishers, Pretoria.

Dippenaar-Schoeman, A.S., 2017, 'Feedback on the Spider Red Listing Project (SRLP)', SANSA News 29, 3.

Dippenaar-Schoeman, A.S., De Jager, M. \& Van den Berg, A., 1996a, 'Behaviour and biology of two species of termite-eating spiders, Ammoxenus amphalodes and $A$. daedalus (Araneae: Ammoxenidae), in South Africa', African Plant Protection 2, 15-17.

Dippenaar-Schoeman, A.S., De Jager, M. \& Van den Berg, A., 1996b, 'Ammoxenus species (Araneae: Ammoxenidae) - Specialist predators of harvester termites in South Africa', African Plant Protection 2, 103-109.

Dippenaar-Schoemanl, A.S., Foord, S.H. \& Haddad, C.R., 2013, Spiders of the Savanna Biome, University of Venda, Thohoyandou \& Agricultural Research Council, Pretoria.

Dippenaar-Schoeman, A.S. \& Haddad, C.R., 2006, 'What is the South African National Survey of Arachnida (SANSA) all about?', SANSA News 1, 1-3.

Dippenaar-Schoeman, A.S., Haddad, C.R., Foord, S.H., Lyle, R., Helberg, L. \& Mathebula, S., 2010, First Atlas of the Spiders of South Africa (Arachnida: Araneae), ARC - Plant Protection Research Institute, Pretoria.

Dippenaar-Schoeman, A.S., Haddad, C.R., Foord, S.H., Lyle, R., Lotz, L.N. \& Marais, P., 2015, 'South African National Survey of Arachnida (SANSA): Review of current knowledge, constraints and future needs for documenting spider diversity (Arachnida: Araneae)', Transactions of the Royal Society of South Africa 70, 245-277. https://doi.org//10.1080/0035919X.2015.1088486

Dippenaar-Schoeman, A.S., Lyle, R. \& Van den Berg, A.M., 2012, 'Bioinformatics on the spiders of South Africa', Serket 13, 121-127.

Dippenaar-Schoeman, A.S. \& Van den Berg, A.M., 2010, Spiders of the Kalahari, Plant Protection Handbook No. 17, Agricultural Research Council, Pretoria.

Foord, S.H., Dippenaar-Schoeman, A.S. \& Haddad, C.R., 2011a, 'South African spider diversity: African perspectives on the conservation of a mega-diverse group', in $\mathrm{O}$. Grillo \& G. Venora (eds.), Changing diversity in changing environment, pp. 163-182, In Tech Publishing, Rijeka.

Foord, S.H., Dippenaar-Schoeman, A.S. \& Haddad, C.R., 2011b, 'The faunistic diversity of spiders (Arachnida, Araneae) of the Savanna Biome in South Africa', Transactions of the Royal Society of South Africa 66, 170-201. https://doi.org/10. 1080/0035919X.2011.639406

Haddad, C.R. \& Dippenaar-Schoeman, A.S., 2005, 'Epigeic spiders (Arachnida: Araneae) in Nama Karoo grassland in the Northern Cape Province', Navorsinge van die Nasionale Museum, Bloemfontein 21, 1-10.

Haddad, C.R. \& Dippenaar-Schoeman, A.S., 2006, 'Epigeic spiders (Araneae) in pistachio orchards in South Africa', African Plant Protection 12, 12-22.

Haddad, C.R. \& Dippenaar-Schoeman, A.S., 2015, 'Diversity of non-acarine arachnids of the Ophathe Game Reserve, South Africa: Testing a rapid sampling protocol', Koedoe 57, 1255. https://doi.org/10.4102/koedoe.v57i1.1255

Haddad, C.R., Dippenaar-Schoeman, A.S. \& Pekár, S., 2005, 'Arboreal spiders (Arachnida: Araneae) in pistachio orchards in South Africa', African Plant Protection 11, 32-41.

Haddad, C.R., Louw, S.vdM. \& Dippenaar-Schoeman, A.S., 2004, 'Spiders (Araneae) in ground covers of pistachio orchards in South Africa', African Plant Protection 10, 97-107.

Haddad, C.R., Louw, S.vdM. \& Pekár, S., 2008, 'Commercial pistachio orchards maintain lower density and diversity of spiders (Araneae): A study from South Africa', African Plant Protection 14, 24-36.

Low, A.B. \& Rebelo, A.G., 1998, Vegetation of South Africa, Lesotho and Swaziland, 2nd edn., Department of Environmental Affairs and Tourism, Government Printers, Pretoria.

Lyle, R. \& Dippenaar-Schoeman, A.S., 2013, 'Sampling in the Diamond Route Reserves', SANSA Newsletter 18, 10.

Lyle, R. \& Dippenaar-Schoeman, A.S., 2015, 'Red Listing of South African spiders', SANSA Newsletter 23, 1.

Lyons, C.-L., 2009, 'Evaluating restoration success of alluvial diamond mined sites in South Africa using invertebrate community indicators', Unpublished MSc thesis, University of Cape Town.

McGeoch, M.A., Sithole, H., Samways, M.J., Simaika, J.P., Pryke, J.S., Picker, M. et al., 2011, 'Conservation and monitoring of invertebrates in terrestrial protected areas', Koedoe 53, 1000. https://doi.org/10.4102/koedoe.v53i2.1000

Petráková, L., Líznarová, E., Pekár, S., Haddad, C.R., Sentenská, L. \& Symondson, W.O.C., 2015, 'Discovery of a monophagous true predator, a specialist termiteeating spider (Araneae: Ammoxenidae)', Scientific Reports 5, 14013. https://doi. org/0.1038/srep14013

Van Rooyen, N., 1999, The vegetation types and veld condition of Tswalu Private Desert Reserve, Unpublished report to the management of Tswalu Kalahari Reserve.

Vasconcellos-Neto, J., Romero, G.O., Santos, A.J. \& Dippenaar-Schoeman, A.S., 2007, 'Association of spiders of the genus Peucetia (Oxyopidae) with plants bearing glandular 'Association of spiders of the genus Peucetia (Oxyopidae) with plants bearing glandu
hairs', Biotropica 39, 221-226. https://doi.org/10.1111/j.1744-7429.2006.00250.x

Webb, P., 2013, 'Defense mechanism in burrow-dwelling wolf spiders', SANSA News 18, 4. 


\section{Appendix 1}

TABLE 1-A1: Checklist of the spiders of Tswalu Kalahari Reserve with guild, endemicity (EN) and conservation status (CS).

\begin{tabular}{|c|c|c|c|c|}
\hline Family & Species & GUILD & EN & CS \\
\hline \multirow[t]{4}{*}{ Agelenidae } & Agelena australis Simon, 1896 & FWB & 1 & LC \\
\hline & Agelena gaerdesi Roewer, 1955 & FWB & 2 & LC \\
\hline & Benoitia sp.* & FWB & DDT & NEW \\
\hline & Maimuna sp.* & FWB & DDT & NEW \\
\hline Ammoxenidae & Ammoxenus coccineus Simon, 1893 & FGW & 2 & LC \\
\hline \multirow[t]{9}{*}{ Araneidae } & Araneus apricus (Karsch, 1884) & OWB & 1 & LC \\
\hline & Argiope australis (Walckenaer, 1805) & OWB & 1 & LC \\
\hline & Argiope lobata (Pallas, 1772) & OWB & 1 & LC \\
\hline & Caerostris sexcuspidata (Fabricius, 1793) & OWB & 1 & LC \\
\hline & Cyrtophora citricola (Forsskål, 1775) & MOWB & 0 & LC \\
\hline & Isoxya mossamedensis Benoit, 1962 & OWB & 2 & LC \\
\hline & Larinia chloris (Audouin, 1826) & OWB & 1 & LC \\
\hline & Nemoscolus tubicola (Simon, 1887) & OWB & 2 & LC \\
\hline & Neoscona blondeli (Simon, 1885) & OWB & 1 & LC \\
\hline \multirow[t]{2}{*}{ Caponiidae } & Caponia capensis Purcell, 1904 & FGW & 2 & LC \\
\hline & Diploglena sp. imm. & FGW & DDT & IMM. \\
\hline Clubionidae & Clubiona aspidiphora Simon, 1910 & PW & 2 & LC \\
\hline Cyrtaucheniidae & Ancylotrypa pusilla Purcell, 1903 & BGW & 5 & NCE \\
\hline Dictynidae & Archaeodictyna condocta (O.P.-Cambridge, 1876) & RWB & 0 & LC \\
\hline \multirow[t]{4}{*}{ Eresidae } & Dresserus laticeps Purcell, 1904 & RWB & 5 & NCE \\
\hline & Gandanameno fumosa (C.L. Koch, 1837) & RWB & 2 & LC \\
\hline & Stegodyphus africanus (Blackwall, 1866) & RWB & 1 & LC \\
\hline & Stegodyphus dumicola Pocock, 1898 & RWB & 2 & LC \\
\hline \multirow[t]{2}{*}{ Eutichuridae } & Cheiracanthium furculatum Karsch, 1879 & PW & 1 & LC \\
\hline & Cheiramiona simplicitarsis (Simon, 1910) & PW & 3 & SAE \\
\hline \multirow[t]{9}{*}{ Gnaphosidae } & Aneplasa nigra Tucker, 1923 & FGW & 4 & SAE \\
\hline & Asemesthes ceresicola Tucker, 1923 & FGW & 3 & SAE \\
\hline & Asemesthes lineatus Purcell, 1908 & FGW & 2 & LC \\
\hline & Megamyrmaekion transvaalense Tucker, 1923 & FGW & 3 & SAE \\
\hline & Micaria sp. $1^{*}$ & FGW & DDT & NEW \\
\hline & Trichothyse africana (Tucker, 1923) & FGW & 3 & SAE \\
\hline & Xerophaeus aridus Purcell, 1907 & FGW & 2 & LC \\
\hline & Zelotes corrugatus (Purcell, 1907) & FGW & 1 & LC \\
\hline & Zelotes ovambensis Lawrence, 1927 & FGW & 1 & LC \\
\hline \multirow[t]{3}{*}{ Hersiliidae } & Hersilia sericea Pocock, 1898 & PW & 1 & LC \\
\hline & Hersilia setifrons Lawrence, 1928 & PW & 2 & LC \\
\hline & Tyrotama australis (Simon, 1893) & FGW & 2 & LC \\
\hline \multirow[t]{2}{*}{ Linyphiidae } & Agyneta habra (Locket, 1968) & SHWB & 1 & LC \\
\hline & Pelecopsis janus Jocqué, 1984 & SHWB & 2 & LC \\
\hline \multirow[t]{6}{*}{ Lycosidae } & Allocosa aurichelis Roewer, $1959 ?$ & FGW & 5 & NCE \\
\hline & Evippomma squamulatum (Simon, 1898) & FGW & 2 & LC \\
\hline & Hogna transvaalica (Simon, 1898)? & BGW & 3 & SAE \\
\hline & Minicosa neptuna Alderweireldt \& Jocqué, 2006 & FGW & 3 & SAE \\
\hline & Pardosa crassipalpis Purcell, 1903 & FGW & 2 & LC \\
\hline & Trabea ornatipalpis Russell-Smith, 1982 & FGW & 3 & SAE \\
\hline Migidae & Moggridgea peringueyi Simon, 1903 & BGW & 3 & SAE \\
\hline Mimetidae & Ero sp.* & PW & DDT & NEW \\
\hline \multirow[t]{6}{*}{ Oxyopidae } & Hamataliwa kulczynskii (Lessert, 1915) & PW & 1 & LC \\
\hline & Oxyopes bothai Lessert, 1915 & PW & 1 & LC \\
\hline & Oxyopes hoggi Lessert, 1915 & PW & 1 & LC \\
\hline & Oxyopes jacksoni Lessert, 1915 & PW & 1 & LC \\
\hline & Oxyopes russoi Caporiacco, 1940 & PW & 1 & LC \\
\hline & Peucetia viridis (Blackwall, 1858) & PW & 1 & LC \\
\hline \multirow[t]{2}{*}{ Palpimanidae } & Diaphorocellus biplagiatus Simon, 1893 & FGW & 2 & LC \\
\hline & Palpimanus namaquensis Simon, 1910 & FGW & 2 & LC \\
\hline
\end{tabular}


TABLE 1-A1 (Continues...): Checklist of the spiders of Tswalu Kalahari Reserve with guild, endemicity (EN) and conservation status (CS).

\begin{tabular}{|c|c|c|c|c|}
\hline Family & Species & GUILD & EN & CS \\
\hline \multirow[t]{6}{*}{ Philodromidae } & Gephyrota glauca (Jézéquel, 1966) & PW & 1 & LC \\
\hline & Hirriusa arenacea (Lawrence, 1927) & FGW & 2 & LC \\
\hline & Philodromus bigibbus (O.P.-Cambridge, 1876) & PW & 1 & LC \\
\hline & Philodromus browningi Lawrence, 1952 & PW & 2 & LC \\
\hline & Philodromus sp.* & PW & DDT & NEW \\
\hline & Tibellus minor Lessert, 1919 & PW & 1 & LC \\
\hline Pholcidae & Smeringopus lotzi Huber, 2012 & SPWB & 3 & SAE \\
\hline \multirow[t]{2}{*}{ Pisauridae } & Euprosthenops australis Simon, 1898 & SHWB & 1 & LC \\
\hline & Euprosthenopsis vuattouxi Blandin, 1977 & FWB & 1 & LC \\
\hline \multirow[t]{3}{*}{ Prodidomidae } & Prodidomus purpurascens Purcell, 1904 & FGW & 4 & SAE \\
\hline & Theuma foveolata Tucker, 1923 & FGW & 2 & LC \\
\hline & Theuma maculata Purcell, 1907 & FGW & 2 & LC \\
\hline \multirow[t]{17}{*}{ Salticidae } & Aelurillus cristatopalpus Simon, 1902 & FGW & 5 & NCE \\
\hline & Cembalea triloris Haddad \& Wesołowska, 2011 & FGW & 2 & LC \\
\hline & Heliophanus trepidus Simon, 1910 & PW & 1 & LC \\
\hline & Hyllus dotatus (Peckham \& Peckham, 1903) & FGW/PW & 1 & LC \\
\hline & Icius insolidus (Wesołowska, 1999) & FGW/PW & 2 & LC \\
\hline & Langona hirsuta Haddad \& Wesołowska, 2011 & FGW & 3 & SAE \\
\hline & Langona warchalowskii Wesołowska, 2007 & FGW & 4 & SAE \\
\hline & Langelurillus namibicus Wesołowska, 2011 & FGW & 2 & LC \\
\hline & Myrmarachne sp. imm. & PW & DDT & IMM. \\
\hline & Natta horizontalis Karsch, 1879 & FGW & 1 & LC \\
\hline & Pellenes epularis (O. P.-Cambridge, 1872) & FGW & 0 & LC \\
\hline & Pellenes geniculatus (Simon, 1868) & FGW & 0 & LC \\
\hline & Pellenes tharinae Wesołowska, 2006 & FGW & 2 & LC \\
\hline & Phlegra karoo Wesołowska, 2006 & FGW & 2 & LC \\
\hline & Salticidae sp. (new genus)* & FGW & DDT & NEW \\
\hline & Tanzania parvulus Wesołowska, Azarkina \& Russell-Smith, 2014 & FGW & 3 & SAE \\
\hline & Tusitala barbata Peckham \& Peckham, 1902 & PW & 1 & LC \\
\hline Scytodidae & Scytodes arenacea Purcell, 1904 & FGW & 2 & LC \\
\hline Selenopidae & Anyphops barnardi (Lawrence, 1940) & FGW & 3 & SAE \\
\hline \multirow[t]{3}{*}{ Segestriidae } & Ariadna jubata Purcell, 1904 & RWB & 5 & NCE \\
\hline & Ariadna karrooica Purcell, 1904 & RWB & 4 & SAE \\
\hline & Ariadna lightfooti Purcell, 1904 & RWB & 4 & SAE \\
\hline \multirow[t]{2}{*}{ Sicariidae } & Loxosceles simillima Lawrence, 1927 & FGW & 2 & LC \\
\hline & Sicarius testaceus Purcell, 1908 & FGW & 3 & SAE \\
\hline \multirow[t]{3}{*}{ Sparassidae } & Arandisa deserticola Lawrence, 1938? & FGW & 2 & LC \\
\hline & Eusparassus schoemanae Moradmand, 2013 & FGW & 2 & LC \\
\hline & Olios correvoni Lessert, 1921 & PW & 1 & LC \\
\hline \multirow[t]{3}{*}{ Theraphosidae } & Harpactira sp. & BGW & DDT & IMM. \\
\hline & Harpactirella lapidaria Purcell, 1908 & BGW & 5 & NCE \\
\hline & Idiothele nigrofulva (Pocock, 1898) & BGW & 2 & LC \\
\hline \multirow[t]{8}{*}{ Theridiidae } & Euryopis episinoides (Walckenaer, 1847) & GWB & 0 & LC \\
\hline & Histagonia deserticola Simon, 1895 & GWB & 5 & NCE \\
\hline & Latrodectus geometricus C.L. Koch, 1841 & GWB & 0 & LC \\
\hline & Latrodectus renivulvatus Dahl, 1902 & GWB & 1 & LC \\
\hline & Phoroncidia eburnea (Simon, 1895) & GWB & 3 & SAE \\
\hline & Steatoda grossa (C.L. Koch, 1838) & GWB & 0 & LC \\
\hline & Theridion purcelli O.P.-Cambridge, 1904 & GWB & 1 & LC \\
\hline & Thwaitesia sp. & GWB & DDT & IMM. \\
\hline \multirow[t]{6}{*}{ Thomisidae } & Diaea puncta Karsch, 1884 & PW & 1 & LC \\
\hline & Heriaeus zani Van Niekerk \& Dippenaar-Schoeman, 2013 & PW & 3 & SAE \\
\hline & Holopelus albibarbis Simon, 1895 & PW & 1 & LC \\
\hline & Misumenops rubrodecoratus Millot, 1942 & PW & 1 & LC \\
\hline & Monaeses austrinus Simon, 1910 & PW & 1 & LC \\
\hline & Monaeses paradoxus Lucas, 1864 & PW & 1 & LC \\
\hline
\end{tabular}


TABLE 1-A1 (Continues...): Checklist of the spiders of Tswalu Kalahari Reserve with guild, endemicity (EN) and conservation status (CS).

\begin{tabular}{|c|c|c|c|c|}
\hline Family & Species & GUILD & EN & CS \\
\hline & Stiphropus affinis Lessert, 1923 & PW & 3 & SAE \\
\hline & Synema decens (Karsch, 1878) & PW & 3 & SAE \\
\hline & Synema imitator (Pavesi, 1883) & PW & 1 & LC \\
\hline & Synema nigrotibiale Lessert, 1919 & PW & 1 & LC \\
\hline & Thomisops sulcatus Simon, 1895 & PW & 1 & LC \\
\hline & Thomisus dalmasi Lessert, 1919 & PW & 1 & LC \\
\hline & Tmarus africanus Lessert, 1919 & PW & 1 & LC \\
\hline & Xysticus mulleri Lawrence, 1952 & FGW & 3 & $\mathrm{SAE}$ \\
\hline & Xysticus namaquensis Simon, 1910 & FGW & 1 & LC \\
\hline \multirow[t]{3}{*}{ Uloboridae } & Uloborus planipedius Simon, 1896 & OWB & 1 & LC \\
\hline & Uloborus plumipes Lucas, 1846 & OWB & 1 & LC \\
\hline & Uloborus walckenaerius Latreille, 1806 & OWB & 0 & LC \\
\hline \multirow[t]{2}{*}{ Zodariidae } & Caesetius flavoplagiatus Simon, 1910 & FGW & 2 & LC \\
\hline & Mallinus nitidiventris Simon, 1893 & FGW & 4 & SAE \\
\hline
\end{tabular}

*, new species.

GUILDS: BGW, burrow-dwelling ground wanderers; FGW, free-living ground wanderers; FWB, funnel-web builders; GWB, gumfoot-web builders; MOWB, modified orb-web builders; OWB, orb-web builders; PW, plant wanderers; RWB, retreat-web builders; SHWB, sheet-web builders; SPWB, space-web builders.

ENDEMICITY: seven endemicity categories, ranging from: 5, known from one province only, wider than type locality; 4, known from two adjoining provinces only; 3 , South African endemic, greater than two provinces or provinces not adjoining; 2, southern Africa (south of Zambezi and Kunene Rivers); 1, Afrotropical Region; 0, Africa and wider; DDT, data deficient for taxonomic reasons (possibly new or immature).

Conservation status: LC, least concern species having a wide distribution throughout Africa falling in range 0-2; SAE, South African Endemic (3, 4); NCE, Northern Cape Endemics (5); NEW, possible new species; IMM., only known from immature specimens. 